\section{Idealism and Utilitarianism in Internationalization of Higher Education}

ROGER Y. CHAO, JR.

Roger Y. Chao, Jr. holds a PhD on Asian and International Studies from the City University of Hong Kong, and currently an international consultant in higher education for UNESCO. E-mail: rylimchao@yahoo. com.

Thternationalization of higher education is increasingly 1 becoming a key policy directive across nation states and regions, as a result of the increased interdependency brought about by the twin processes of globalization and regionalization. Thus, higher education is increasingly becoming a production line for the global competence and skilled human capital required by the global knowledgebased labor market.

Internationalization of higher education has become a broad term meaning several (and at times overlapping or contradicting) ideas and activities - in particular, academic and student mobility, international research collaboration, cross-border and transnational education, offering programs in English, and using international curricula and textbooks. The establishment of the global higher education market, financing challenges of higher education institutions, reconceptualization of higher education as a private good, and the increased demand and massification of higher education, have all encouraged its utilitarianism.

These developments are taking place within a changing world order that has reshaped the relationship among nation states and their respective higher education systems, established new transnational/supranational governance structures, and facilitated diversity in the delivery of public services, including higher education. This article highlights the two extremes, idealism, and utilitarianism, of internationalization of higher education within a changing world order, in order to provide a basis for understanding its multiple meanings and functions.

\section{The Changing World Order}

The end of the Second World War saw a rapidly changing world order, including global and regional peace-building initiatives and the establishment of new nation-states and regions. Most of the silos between nation-states have disappeared and been replaced by increased interdependency between nation-states, the establishment of regions and their respective regional institutions. As such, the world order is increasingly shifting into a world of regions and will continue evolving into another form in the future. This shift in the world order has been made possible with the advancement of information and communications technology (ICT), the advent of cheap travel, the end of the Cold War, increased political and economic interdependency, and the demographic challenges of the developed world. Developing Asia's demographic premium not only supplies human capital to the world but also serves as a major market for international higher education.

This changing world order has impacted higher education, changed the higher education environment, and shifted the meaning and nature of internationalization of higher education. Higher education has now become a policy instrument to support sustainable economic development. The global race for talent emphasizes students as future laborers rather than being citizens of nation-states, regions, and the world. These developments have led to higher education being viewed as a private good. Its massification, decreased public-sector financing, and multilateral initiatives have redefined education as a tradable commodity and established the global higher education market.

\section{As the increasingly interdependent world order necessitates, higher educa- tion curricula need to be international- ized but not to the extent of reducing local knowledge and culture into one homogenized international standard.}

\section{Shifting and Multiple Meanings of Internationaliza- TION}

The changing world order and the establishment of the global higher education market have set the tone for the shifting and multiple meanings and nature of internationalization of higher education. Advancement in ICT, reduced trade barriers, and an increased openness to labor mobility due to demographic challenges and the shortage of skilled and competent labor in developed nation states also play a role in pushing for the utilitarian function of internationalization of higher education.

In spite of the university's international nature, internationalization of higher education is a recent phenomenon of the I980s and I990s, where the focus was on social and political rationales. The changing world order, however, has greatly impacted the meaning and nature of internationalization of higher education, with the last 25 years focused on more economically driven rationales. Aside from the preparation of globally competent human capital, 
it has predominantly become a commercialized endeavor with its potential to help finance higher education institutions, serve as a gateway for immigration, and a filtering mechanism for host nation states.

Global labor and student mobility, however, has increasingly shifted from the traditional South-North dynamic to South-South engagement and, to a lesser extent (and primarily in relation to credit mobility) a North-South direction, given the global production chain, outsourcing of production and various other processes, and the advent of multinational corporations. Cross-border and transnational programs have been established in part due to financing challenges of higher education institutions in the Global North, but also due to the growing demand for higher education in emerging economies, particularly in Asia and the Middle East.

Nation-states' sovereignty over higher education has increasingly been challenged as their respective higher education institutions and systems embrace internationalization by introducing international "English medium" programs and curricula, undertaking joint programs, and inviting foreign higher education institutions into their territory and national higher education systems. This enhances the commercialization of higher education and the increasing focus of internationalization of higher education's utilitarianism.

\section{Internationalization of higher education has become a broad term meaning sev- eral (and at times overlapping or contra- dicting) ideas and activities.}

\section{IDEALISM AND UTILITARIANISM}

The higher education sector, however, is not limited to its utilitarian function of producing human capital for national and regional economic development. The universities' traditional roles as ivory towers for societal development, knowledge production, and eventually molding global citizens and the world's future leaders, simply conflict with this utilitarian function. In fact, civic engagement, addressing global social problems, and millennium goals should be incorporated into universities' core missions.

Internationalization of higher education has political, socioeconomic, cultural and academic rationales, and is simultaneously a top-down and bottom-up process. Furthermore, internationalization occurs within and outside of national higher education systems. As such, it goes beyond the increased and seemingly institutionalized focus on international faculty and student mobility, cross-border and transnational education, and research collaboration. It should incorporate an ongoing dialogue and negotiation of national, regional, and global knowledge, skills and competencies requirements, and national, regional, and global needs within a changing world order.

Ideally, internationalization of higher education should not only take into account the changing world order and its economic rationale, but also the political, cultural, and academic rationales, which include identity formation, societal betterment, and the development of global citizens. As the increasingly interdependent world order necessitates,

\section{Higher education has now become a policy instrument to support sustain- able economic development.}

higher education curricula need to be internationalized but not to the extent of reducing local knowledge and culture into one homogenized international standard. The diversity across regions and nation-states requires internationalization from above and below to mold global citizens who are culturally adept and competent to contribute to the various grand challenges of the changing world order, such as human rights, poverty alleviation, environmental protection, and sustainable development.

Idealism and utilitarianism are present in internationalization of higher education across the world. Internationalization of higher education, its meanings and functions, actually represent a hybrid of idealism and utilitarism which differs based on the political, socioeconomic, cultural and historical development of a nation state or region. In spite of top down pressures brought about by globalization and regionalization, the bottom up pressures located within nation-states influence how internationalization of higher education is defined and utilized.

Internationalization of higher education should be seen holistically with its multiple dimensions (including political, socioeconomic, cultural, and academic), across multiple levels (global, regional, and national), and within the processes of globalization and regionalization. Each block of this matrix would offer slightly different meanings and functions of internationalization of higher education, but falls within the two extremes of idealism and utilitarianism. 